\title{
PENGARUH PARTISIPASI DAN KETIDAKPASTIAN TUGAS DALAM PENGEMBANGAN SISTEM INFORMASI MANAJEMEN PADA KINERJA SISTEM INFORMASI (STUDI PADA PTS DI LINGKUNGAN KOPERTIS WILAYAH V-DIY)
}

\author{
Heru Kurnianto Tjahjono* \\ Herland Alfa Stevany \\ Universitas Muhammadiyah Yogyakarta
}

\begin{abstract}
Today, information systems in business even more important than a few years ago. Information technology (IT) innovations and global business environment makes the role of IT in information systems more dominant. That role of IT can enhance human resources role compete globally. Higher education institutions as places for develop human resources is required to optimize information systems performance. This research identified two antecedents of information systems performance. There are user participation and task uncertainty. Besides that, this research considere size of organization as moderating variable. We separate size become two proxies. University as represent high size complexity and non university as represent as low size complexity. The purpose of this research is to analyze user participation and task uncertainty as antecedents of information systems performance and consider size of organization, higher education institutions. Samples are several higher education institutions in Jogjakarta province. In general the result partially supported the hypothesis that user participation and task uncertainty are predictor of information systems performance and size of organization is considered as moderating variable partially.
\end{abstract}

Keywords: user participation, task uncertainty, and information systems performance.

\section{Pendahuluan}

Kajian tentang partisipasi pemakai, ketidakpastian tugas dan kinerja sistem informasi dalam organisasi merupakan topik yang penting untuk diteliti. Dalam dunia praktek partisipasi karyawan dalam implementasi sistem informasi dan derajat ketidakpastian tugas menjadi determinan utama dalam menjelaskan kinerja sistem informasi. Hal tersebut menunjukkan pentingnya pemahaman informasi dalam menyelesaikan pekerjaan-pekerjaan dan partisipasi mereka dalam melaksanakan tugas (Rokart dan Flanery,1983).

Isu yang penting dalam organisasi adalah bagaimana sistem informasi dapat berperan penting dalam menyelesaikan permasalahan dan memudahkan proses dalam organisasi. Isu yang terkait dengan hal tersebut berkaitan dengan bagaimana keterlibatan pengguna dalam implementasi sistem informasi. Harapannya apabila keterlibatan karyawan tinggi menjadikan proses implementasi adalah bagian dari mereka. Dengan demikian keadilan sistem informasi dipersepsikan dan diharapkan dapat menjadi solusi atas permasalahanpermasalahan manajerial organisasi, bukan sebaliknya menambah permasalahan dalam organisasi tersebut. 
Pada sisi lain, derajat ketidakpastian tugas yang dihadapi karyawan pengembangan sistem informasi merupakan hal penting dalam menjelaskan kinerja sistem informasi. Apabila derajat ketidakpastian tugas tinggi akan dapat membingungkan para karyawan dalam organisasi tersebut, sehingga berpengaruh pula pada kinerja mereka.

Fenomena di atas dapat menyebabkan pencapaian kinerja sistem informasi tidak maksimal karena karyawan tidak dapat langsung melaksanakan tugasnya. Proporsi informasi yang diterima karyawan dari pihak manajer dan yang tersedia di dalam sistem informasi tidak sesuai. Keterlibatan manajer dan karyawan baik pengguna maupun perancang sistem informasi akan dapat mendorong kinerja para karyawan tersebut. Demikian pula derajat ketidakpastian tugas yang dapat diminimalkan dapat membantu pencapaian kinerja yang lebih baik.

Penelitian ini merupakan modifikasi dari penelitian yang dilakukan oleh Wijayanti dan Solichin (2002) dengan variabel ketidakpastian tugas sebagai variabel pemoderasian. Penelitian tersebut mengambil sampel perguruan tinggi dengan hasil penelitian menunjukan adanya pengaruh positif secara signifikan partisipasi pemakai dan ketidakpastian tugas terhadap kinerja sistem informasi. Keadaan tersebut secara logika akan terwujud lebih baik apabila karayawan dapat meningkatkan tingkat partisipasi pemakai dan organisasi dapat mengurangi tingkat ketidakpastian tugas para karyawan mereka.

\section{Landasan Teori dan Pengembangan Hipotesis}

Keterlibatan atau partisipasi pemakai dalam perencanaan sistem merupakan salah satu faktor yang dapat mempengaruhi kinerja pemakai. (Restuningdiah dan Indriantoro, 1999). Semakin tinggi keterlibatan atau partisipasi pemakai dalam perencanaan sistem menjadikan pemakai merasa turut andil dalam sistem tersebut. Dalam pengembangan sistem informasi, para pemakai menjadi fokus penting berkaitan dengan keefektifan sistem informasi, karena mereka banyak memahami permasalahan di lapangan. Oleh karena itu, setiap perubahan sistem sebagai hasil pengembangan harus mempertimbangkan persoalan-persoalan di lapangan. Keberhasilan pengembangan sistem informasi tidak hanya ditentukan kecanggihan sistem tersebut, tetapi juga ditentukan oleh kesesuaiannya dengan lingkungan kerja, tempat para pemakai menggunakan sistem tersebut. Oleh karena itu, walaupun secara teknis sistem tersebut baik, belum tentu dikatakan berhasil jika pemakai sistem informasi resisten dengan sistem tersebut. Dengan keterlibatan pemakai diharapkan dapat mengurangi derajat resistensi para pemakai dan lebih mengakomodasikan hal-hal di lapangan yang hanya diketahui oleh para pemakai tersebut. Oleh karena itu, apabila pemakai merasa turut berpartisipasi di dalamnya akan dapat mendorong kinerja sistem informasi secara lebih baik. Berdasarkan hal tersebut, peneliti merumuskan hipotesis penelitian sebagai berikut:

H1: Partisipasi pemakai sistem informasi berpengaruh positif pada kinerja sistem informasi. Semakin tinggi tingkat partisipasi pemakai, kinerja sistem informasi semakin baik.

Ketidakpastian tugas merupakan variabel penting yang dapat mempengaruhi kinerja sistem informasi. Semakin tinggi derajat kepastian tugas, seseorang akan sulit berkerja dengan baik. Sebaliknya, semakin rendah derajat ketidakpastian tugas seseorang maka akan semakin mudah dalam melaksanakan aktivitas dan semakin mudah meningkatkan kinerja mereka. 
Menurut Daft et al. (1987 dalam Wijayanti dan Solichin, 2002), derajat ketidakpastian tugas muncul dari ambiguitas dan struktur yang lemah, baik dalam tugas-tugas utama maupun tugas-tugas yang lain yang berkait. Sehingga ketidakpastian tugas secara relatif lebih tinggi untuk tugas-tugas yang "fuzzy dan illdefined", artinya tugas-tugas yang diberikan kurang jelas dalam penyelesaiannya dan lebih rendah untuk tugas-tugas yang sudah terpola dan terstruktur. Untuk tugas-tugas yang membingungkan (ambiguous) dan tidak terstruktur menyebabkan para pemakai atau karyawan tidak dapat bekerja secara optimal sehingga kinerja sistem informasi mereka akan terganggu. Berdasarkan hal tersebut, peneliti merumuskan hipotesis penelitian sebagai berikut:

$\mathrm{H} 2$ : Ketidakpastian tugas dalam penggunaan sistem informasi berpengaruh negatif pada kinerja sistem informasi. Semakin tinggi derajat ketidakpastian tugas maka akan menurunkan kinerja sistem informasi.

Menurut Jen (2002) berpendapat bahwa ukuran organisasi yang besar menunjukkan kompleksitas yang lebih rumit sehingga akan berbeda dengan organisasi dengan kompleksitas yang rendah. Dalam penelitian ini, universitas diproksi sebagai perguruan tinggi yang memiliki kompleksitas yang tinggi, karena terdiri atas beberapa fakultas dan program studi. Sedangkan perguruan tinggi non universitas seperti sekolah tinggi dan akademi diproksi sebagai perguruan tinggi dengan kompleksitas rendah, karena hanya memiliki beberapa program studi saja. Dari pendapat tersebut berarti terdapat perbedaan partisipasi pemakai berdasarkan ukuran organisasi, bahwa semakin besar ukuran organisasi maka akan lebih meningkatkan tingkat partisipasi pemakai. Demikian pula halnya dengan derajat ketidakpastian tugas. Berdasarkan hal tersebut, peneliti merumuskan hipotesis penelitian sebagai berikut :

H3 : Ukuran organisasi memoderasi pengaruh partisipasi pemakai terhadap kinerja sistem informasi.

H4: Ukuran organisasi memoderasi pengaruh ketidakpastian tugas terhadap kinerja sistem informasi.

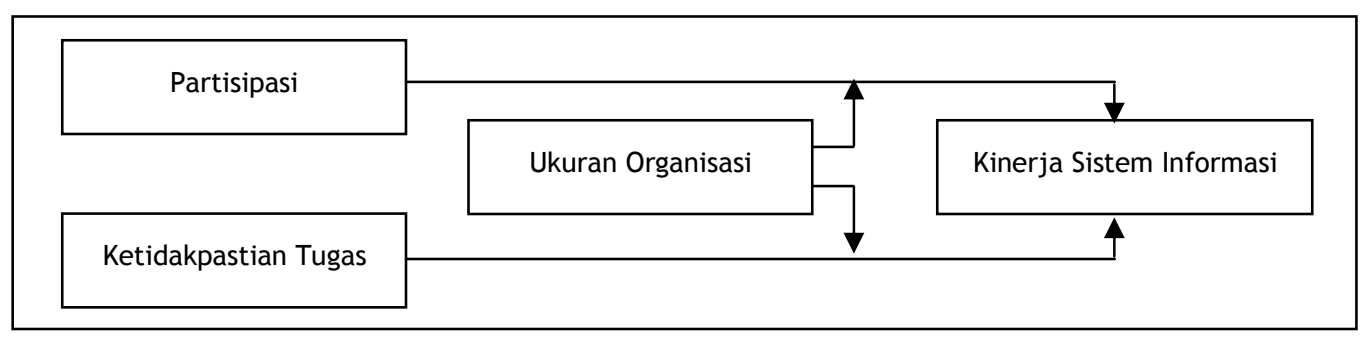

Gambar 1

Model Penelitian Prediksi Partisipasi dan Ketidakpastian Tugas Pada Kinerja Sistem Informasi 


\section{Metode Penelitian}

Subjek penelitian adalah pemakai sistem informasi pada setiap perguruan tinggi yang ada di perguruan tinggi tersebut, yaitu karyawan (level manajer menengah) di bidang akademik dan bagian lain yang sudah menerapkan teknologi informasi. Secara rinci, pemakai sistem informasi adalah para karyawan yang bekerja dalam bidang administratif dan manajerial perguruan tinggi dan mempunyai kemampuan mengambil keputusan secara terbatas berkaitan dengan penggunaan sistem informasi, seperti mengambil kebijakan berkaitan dengan gangguan teknis komputer. Karyawan perguruan tinggi dipilih sebagai responden karena karyawan merupakan pihak yang melaksanakan sistem sehingga diharapkan mereka mampu memberikan penilaian terhadap sistem yang mereka gunakan. Para staf pengajar yang juga menjalankan kegiatan administratif serupa atau ditugaskan sebagai pengelola sistem dianggap sebagai karyawan manajerial dan dimasukkan sebagai subjek.

Data penelitian adalah data primer yaitu persepsi responden tentang partisipasi dalam pengembangan sistem informasi, ketidakpastian tugas kinerja sistem informasi. Data diperoleh dengan cara menyebarkan kuesioner. Survei dilakukan dengan mendatangi secara langsung perguruan tinggi yang dijadikan sampel. Adapun pengelompokkannya seperti tabel di bawah ini:

Tabel 1.

Karakteristik Objek Penelitian

\begin{tabular}{ccccc}
\hline No & $\begin{array}{c}\text { Jenis Perguruan Tinggi } \\
\text { Swasta }\end{array}$ & Jumlah & Jumlah responden & Persentase (\%) \\
\hline Universitas & & & & \\
\hline 1 & Universitas & 13 & 39 & $43 \%$ \\
\multicolumn{2}{l}{ Non Universitas } & & & $30 \%$ \\
\hline 2 & Sekolah Tinggi & 9 & 27 & $27 \%$ \\
3 & Akademi & 8 & 24 & $100 \%$ \\
\hline
\end{tabular}

Pengukuran kinerja adalah suatu gagasan dan proses sistematis untuk mengumpulkan, menganalisa, dan menggunakan sistem informasi utuk mencapai tingkat efisiensi dan efektifitas tugas-tugas karyawan dalam pencapaian tujuan suatu organisasi. Sistem pengukuran kinerja merupakan ukuran tentang apa yang dianggap penting oleh suatu organisasi dan seberapa baik kinerjanya. Karena sistem pengukuran kinerja yang baik dapat menggerakan suatu organisasi pada arah yang positif, maka sistem yang buruk dapat menyebabkan organisasi menyimpang jauh, kelemahan pengukuran kinerja merupakan hambatan utama terhadap kemajuan.

Instrumen ini menggunakan 5 instrumen pertanyaan meliputi kemudahan dalam pemakaian sistem, intensitas pemakaian sistem, konstribusi sistem terhadap pelaksanaan tugas, pencapaian tujuan tugas dan penghematan waktu. Pengukuran dilakukan dengan menggunakan 5 angka instrumen likert yang dimulai angka 5 sangat puas sampai angka 1 sangat tidak puas. Variabel kinerja sistem informasi ini mengacu pada instrumen yang digunakan oleh Astuti (2003).

Partisipasi pemakai, adalah variabel independen yang didefinisikan sebagai tindakan sejauh mana anggota organisasi diikutsertakan dalam aktivitas-aktivitas yang berkaitan dengan 
pengembangan sistem informasi (Nizarul, 1998). Menurut (Barki dan Hartwick, 1994) partisipasi adalah perilaku, pekerjaan, dan aktivitas yang dilakukan oleh pemakai selama proses perancangan dan pengembangan sistem informasi. Pemakai akan memainkan peran yang besar dalam peningkatan design dan pengembangan sistem informasi (Loudon, 1996). Instrumen yang digunakan dalam penelitian ini adalah instrumen yang sama digunakan oleh peneliti sebelumnya yakni (Indriantoro dan Setianingsih, 1998; Chandrarin dan Indriantoro, 1997 dalam Wijayanti dan Solichin, 2002) yang merupakan hasil pengembangan oleh Ives dan Olson, (1984) dan telah dimodifikasi sedemikian rupa oleh McKeen et al. (1994), yang terdiri dari 7 instrumen pertanyaan yang mengukur adanya partisipasi dari pemakai selama pengembangan sistem informasi mulai dari tahap perencanaan sampai dengan tahap implementasi.

Ketidakpastian tugas, adalah variabel independen yang didefinisikan sebagai persepsi individu mengenai kesulitan ataupun kerumitan suatu tugas. Hal ini menunjukkan pentingnya pemahaman informasi dalam melaksanakan tugas. Kriteria tugas yang pasti akan mendorongan pencapaian tugas secara tepat, sehingga akan bermanfaat dalam pembuatan keputusan (Brown dan Bostom, 1994 dalam Wijayanti dan Solichin, 2002). Variabel ketidakpastian tugas diukur berdasarkan tingkat pemahaman tugas, penelitian ini akan menggunakan daftar pertanyaan yang berisikan 5 instrumen pertanyaan, intrumen tersebut diukur dengan menggunakan 5 (lima) instrumen likert dimulai dari angka 1 (satu) sangat puas sampai angka 5 (lima) sangat tidak puas, di mana angka 3(tiga) merupakan nilai netral.

\section{Hasil Penelitian dan Pembahasan}

Berdasarkan hasil analisis faktor partisipasi pemakai maka didapat nilai KMO sebesar 0.640 sehingga termasuk baik dan dapat dipertanggung jawabkan, muatan faktor dapat ditabulasikan dalam tabel berikut:

Tabel 2

Validitas Instrumen Partisipasi Pemakai

\begin{tabular}{ccc}
\hline No Butir & Variabel & Muatan Faktor \\
\hline 1 & Instrumen 1 partisipasi & 0,672 \\
2 & Instrumen 2 partisipasi & 0,532 \\
3 & Instrumen 3 partisipasi & 0,476 \\
4 & Instrumen 4 partisipasi & 0,495 \\
5 & Instrumen 5 partisipasi & 0,588 \\
6 & Instrumen 6 partisipasi & 0,675 \\
7 & Instrumen 7 partisipasi & 0,502 \\
\hline Sumber: Data primer diolah. 2007
\end{tabular}

Berdasarkan Tabel 2 di atas dapat diketahui bahwa ternyata terdapat instrumen yang mempunyai nilai muatan faktor di bawah 0,5 (Gozhali, 2001) yaitu instrumen 3 dan instrumen 4 sehingga harus direduksi dan tidak diikutkan lagi dalam uji selanjutnya. Setelah mereduksi butir instrumen 3 dan instrumen 4 maka didapat nilai KMO sebesar 0,685 sehingga termasuk baik yang berarti ketepatan analisis faktor dapat dipertanggung jawabkan. Adapun besarnya muatan faktor setelah mereduksi instrumen 3 dan instrumen 4 dapat ditabulasikan dalam Tabel 3. Berdasarkan Tabel 3, dapat diketahui bahwa ternyata tidak terdapat instrumen yang mempunyai nilai muatan faktor di bawah 0,5 sehingga dapat diikutkan dalam uji selanjutnya. 
Tabel 3

Validitas Instrumen Partisipasi Pemakai

\begin{tabular}{ccc}
\hline No Butir & Variabel & Muatan faktor \\
\hline 1 & Instrumen 1 partisipasi & 0,609 \\
2 & Instrumen 2 partisipasi & 0,600 \\
5 & Instrumen 5 partisipasi & 0,612 \\
6 & Instrumen 6 partisipasi & 0,753 \\
7 & Instrumen 7 partisipasi & 0,541 \\
\hline
\end{tabular}

Sumber: Data primer diolah, 2007

Berdasarkan hasil analisis faktor ketidakpastian tugas maka didapat nilai KMO sebesar 0,523 sehingga termasuk baik dan dapat dipertanggung jawabkan. Adapun besarnya muatan faktor dapat ditabulasikan dalam tabel berikut:

Tabel 4

Validitas Instrumen Ketidakastian Tugas

\begin{tabular}{ccc}
\hline No butir & \multicolumn{1}{c}{ Variabel } & Muatan faktor \\
\hline 1 & Instrumen 1 ketidakpastian tugas & 0,795 \\
2 & Instrumen 2 ketidakpastian tugas & 0,461 \\
3 & Instrumen 3 ketidakpastian tugas & 0,152 \\
4 & Instrumen 4 ketidakpastian tugas & 0,238 \\
5 & Instrumen 5 ketidakpastian tugas & 0,861 \\
\hline
\end{tabular}

Sumber: Data Primer Diolah, 2007

Berdasarkan Tabel 4 di atas dapat diketahuan bahwa ternyata terdapat instrumen yang mempunyai nilai muatan faktor di bawah 0,5 yaitu butir instrumen 2, instrumen 3 dan instrumen 4 sehingga harus direduksi dan tidak diikutkan dalam uji selanjutnya. Setelah mereduksi butir ketiga instrumen tersebut, didapat nilai KMO sebesar 0,510 sehingga termasuk baik berarti ketepatan analisis faktor dapat dipertanggung jawabkan. Adapun besarnya muatan faktor setelah mereduksi ketiga instrumen tersebut dapat ditabulasikan dalam Tabel 5. Berdasarkan Tabel 5, dapat diketahui bahwa ternyata tidak terdapat instrumen yang mempunyai nilai muatan faktor di bawah 0,5 (Gozhali, 2001:271). Dengan demikian, variabel ketidakpastian tugas dapat diikutkan dalam uji selanjutnya.

Tabel 5

Validitas Instrumen Ketidakastian Tugas

\begin{tabular}{ccc}
\hline No Butir & Variabel & Muatan faktor \\
\hline 1 & Instrumen 1 ketidakpastian tugas & 0,876 \\
5 & Instrumen 5 ketidakpastian tugas & 0,876 \\
\hline
\end{tabular}

Sumber: Data primer diolah, 2007

Berdasarkan hasil analisis faktor kinerja sistem maka didapat nilai KMO sebesar 0,567 sehingga termasuk baik yang berarti ketepatan analisis faktor dapat dipertanggungjawabkan. Adapun besarnya muatan faktor dapat ditabulasikan dalam Tabel 6. Berdasarkan Tabel 6 dapat diketahui bahwa ternyata terdapat instrumen yang mempunyai nilai muatan faktor di bawah 0,5 yaitu butir instrumen 4 , instrumen 5 dan instrumen 6 , sehingga harus direduksi, dan tidak diikutkan dalam uji salanjutnya. Setelah mereduksi butir instrument tersebut maka didapat nilai $\mathrm{KMO}$ sebesar 0,553 sehingga termasuk baik yang berarti ketepatan analisis faktor dapat dipertanggungjawabkan. Adapun besarnya muatan faktor setelah mereduksi ketiga instrument tersebut dapat ditabulasikan dalam Tabel 7. Berdasarkan Tabel 7 tersebut, dapat 
diketahui bahwa ternyata tidak terdapat instrumen yang mempunyai nilai muatan faktor di bawah 0,5 (Gozhali, 2001).

Tabel 6

Validitas Instrumen Kinerja Sistem

\begin{tabular}{ccc}
\hline No Butir & Variabel & Muatan faktor \\
\hline 1 & Instrumen 1 kinerja sistem & 0,721 \\
2 & Instrumen 2 kinerja sistem & 0,591 \\
3 & Instrumen 3 kinerja sistem & 0,596 \\
4 & Instrumen 4 kinerja sistem & 0,238 \\
5 & Instrumen 5 kinerja sistem & 0,327 \\
6 & Instrumen 6 kinerja sistem & 0,424 \\
\hline
\end{tabular}

Sumber: Data primer diolah, 2007

Tabel 7

Validitas Instrumen Kinerja Sistem

\begin{tabular}{ccc}
\hline No Butir & Variabel & Muatan Faktor \\
\hline 1 & Instrumen 1 kinerja sistem & 0,776 \\
2 & Instrumen 2 kinerja sistem & 0,581 \\
3 & Instrumen 3 kinerja sistem & 0,689 \\
\hline
\end{tabular}

Sumber: Data primer diolah, 2007

Uji reliabilitas adalah suatu pengujian untuk mengukur sejauh mana hasil suatu pengukuran tetap konsisten, bila dilakukan pengukuran lebih dari satu kali terhadap gejala yang sama dengan menggunakan alat ukur yang sama. Uji reliabilitas dilakukan dengan menghitung Cronbach's alpha dari masing-masing instrumen dalam satu variabel. Instrumen yang digunakan dalam penelitian tersebut harus mempunyai nilai Cronbach's alpha lebih dari 0,4 (Sekaran, 2000)

Tabel 8

Hasil Uji Reliabilitas Instrumen

\begin{tabular}{ccc}
\hline Instrumen & Cronbach Alpha & Kesimpulan \\
\hline Ketidakpastian tugas & 0,698 & Reliabel \\
Partisipasi pemakai & 0,606 & Reliabel \\
Kinerja sistem & 0,428 & Reliabel \\
\hline
\end{tabular}

Sumber: Data primer diolah, 2007

Berdasarkan Tabel 8 di atas dapat disimpulkan bahwa instrument Partisipasi pemakai, ketidakpastian tugas, dan kinerja sistem dalam penelitian ini adalah reliabel karena mempunyai nilai lebih besar dari 0,4.

\section{Hasil dan Pembahasan}

Hasil analisis regresi hirarkikal yang digunakan oleh peneliti bertujuan untuk menjawab $\mathrm{H} 1, \mathrm{H} 2$, H3 dan H4. Setelah dianalisis dengan menggunakan alat bantu SPSS 12 for windows dapat diketahui besarnya pengaruh antara variabel independen yaitu partisipasi pemakai $\left(X_{1}\right)$ dan Ketidakpastian tugas $\left(X_{2}\right)$ dan ukuran organisasi $\left(X_{3}\right)$ sebagai variabel pemoderasi, pada 
variabel dependen yaitu kinerja sistem informasi $(Y)$. Adapun hasil analisis dapat dalam tabel 9 berikut ini:

Tabel 9

Pengujian Moderasi dengan Regresi Hirarkikal

\begin{tabular}{|c|c|c|c|c|}
\hline \multirow{2}{*}{ Variabel } & \multicolumn{3}{|c|}{ Kinerja Sistem Informasi } & \multirow{2}{*}{ Sig } \\
\hline & $\beta$ & Adj R Square & $\Delta$ Adj R Square & \\
\hline Efek Utama: & & 0,179 & & \\
\hline Partisipasi pemakai & 0,081 & & & 0,319 \\
\hline Ketidakpastian tugas & 0,480 & & & 0,001 \\
\hline Ukuran organisasi & $-12,906$ & & 0,179 & 0,314 \\
\hline Efek Interaksi : & & 0,246 & & \\
\hline $\begin{array}{l}\text { Partisipasi pemakai }(X) \\
\text { ukuran organisasi }\end{array}$ & 0,245 & & & 0,029 \\
\hline $\begin{array}{l}\text { Ketidakpastian tugas }(X) \\
\text { ukuran organisasi }\end{array}$ & 0,263 & & 0,067 & 0,172 \\
\hline
\end{tabular}

Dari hasil analisis regresi hirarkikal diketahui bahwa nilai Adjusted $R$ Square sebesar 0,179. Hal ini menunjukkan bahwa varian variabel kinerja sistem informasi dapat dijelaskan sebesar 0,179 atau $17,9 \%$ oleh varian variabel Partisipasi pemakai, Ketidakpastian Tugas dan ukuran organisasi sebagai variabel pemoderasi. Sedangkan sisanya sebesar $82,1 \%$ dijelaskan oleh variabel-variabel lain selain Partisipasi pemakai, Ketidakpastian Tugas dan ukuran organisasi sebagai variabel pemoderasi. Digunakan Adjusted $R$ Square dan bukan $R$ Square, karena nilai Adjusted $R$ Square dapat naik atau turun apabila satu variabel ditambahkan ke dalam model atau lebih akurat (Ghozali, 2002). Berdasarkan Unstandardized Coefficient $\beta$ dapat diperoleh persamaan sebagai berikut :

$\mathrm{Y}=0.081 \mathrm{X}_{1}+0,480 \mathrm{X}_{2}$

a. $\quad \beta_{1}$ koefisien arahnya positif, artinya jika Partisipasi Pemakai $\left(X_{1}\right)$ meningkat maka kinerja sistem informasi akan meningkat, begitu juga sebaliknya jika Partisipasi pemakai $\left(X_{1}\right)$ menurun maka kinerja sistem informasi juga akan menurun.

b. $\beta_{2}$ koefisien arahnya positif, artinya jika Ketidakpastian Tugas $\left(X_{2}\right)$ meningkat maka kinerja sistem informasi akan meningkat, begitu juga sebaliknya jika ketidakpastian tugas $\left(\mathrm{X}_{2}\right)$ menurun maka kinerja sistem inofomasi juga akan menurun.

Dari hasil di atas, juga dapat diketahui bahwa varian variabel partisipasi pemakai mempunyai koefisien regresi tidak signifikan, sehingga variabel partisipasi pemakai tidak berpengaruh pada kinerja sistem informasi dalam pengembangan, dengan demikian hipotesis 1 tidak diterima. Hasil lainnya menunjukkan bahwa ketidakpastian tugas mempunyai pengaruh positif signifikan pada kinerja sistem informasi dalam pengembangan sistem informasi. Dengan demikian hipotesis 2 diterima. Untuk mengetahui hasil pengujian moderasi dapat dilihat dalam tabel berikut ini : 
Tabel 9 menunjukkan bahwa interaksi ketidakpastian tugas dengan ukuran organisasi tidak berpengaruh pada kinerja sistem informasi dengan nilai $\alpha=0,05$. Sedangkan nilai interaksi partisipasi pemakai dengan ukuran organisasi berpengaruh positif pada kinerja sistem informasi. Dengan demikian hipotesis 4 ditolak dan hipotesis 3 diterima, bahwa ukuran organisasi memoderasi partisipasi pemakai terhadap kinerja sistem informasi. Hasil ini didukung penelitian yang pernah dilakukan oleh Jen (2002) yang menyatakan bahwa dalam pengembangan sistem informasi tingkat partisipasi pemakai dipengaruhi oleh ukuran organisasi.

Berdasarkan uji hipotesis 1 diperoleh nilai sig sebesar 0,319 yang lebih besar dibanding alpha (a ) yang dipersyaratkan 0,05 maka HI tidak diterima. Dengan demikian hasil penelitian ini adalah partisipasi pemakai tidak berpengaruh terhadap kinerja sistem informasi. Hasil ini tidak sesuai dengan penelitian yang dilakukan oleh Astuti (2003). Namun menurut Sardana dan Hartati (2005), salah satu penyebab kegagalan yang dialami oleh perusahaan dalam melakukan pengembangan sistem informasi adalah tidak adanya koalisi yang cukup kuat di antara orang-orang yang mempunyai wewenang dan kemampuan untuk mendorong pengembangan sistem informasi. Sehingga para karyawan pengembangan sistem informasi tidak mampu meningkatkan partisipasi dalam pengembangan sistem informasi. Tidak adanya pengaruh partisipasi pengembangan sistem informasi pada kinerja SI dalam konteks perguruan tinggi juga berkaitan dengan orang-orang yang banyak terlibat dalam sistem informasi di kampus banyak yang juga berprofesi sebagai dosen sehingga mereka menggunakan ukuran-ukuran yang berbeda berkaitan dengan kinerja mereka.

Berdasarkan uji hipotesis 2 diperoleh nilai probabilitas 0,001 yang lebih kecil dibanding alpha ( a ) 0,05 maka H2 diterima. Dengan demikian ketidakpastian tugas berpengaruh secara signifikan pada kinerja sistem informasi. Hasil penelitian ini sesuai dengan hasil penelitian sebelumnya yang dilakukan Astuti (2003). Implikasi pada karyawan bagian sistem informasi adalah apabila karyawan merasakan manfaat yang tinggi dari penggunaan komputer dalam pengembangan sistem informasi maka kesulitan yang dihadapi dapat berkurang sehingga ketidakpastian tugas yang dimiliki karyawan rendah. Apabila ketidakpastian tugas rendah, maka karyawan dapat menyelesaikan tugas dalam pengembangan sistem informasi yang telah dibuat sesuai harapan karyawan dan organisasi/instansi/perusahaannya, sehingga kinerja sistem informasi dapat dioptimalkan (Wikanto, 2003). Sesuai teori yang dikemukakan di atas dalam penelitian ini bahwa ketidakpastian tugas berpengaruh positif signifkan pada kinerja sistem informasi. Dengan demikian setiap perancangan sistem informasi hendaknya lebih mengutamakan tingkat kepastian tugas yang diberikan kepada karyawan sistem informasi.

Dalam kaitannya dengan pengembangan sistem informasi, ketika pemakai juga diikutsertakan dalam proses pengembangannya, maka hal itu dapat mengurangi ketidakpastian tugas, jika ketidakpastian tugas rendah maka karyawanpun akan merasa nyaman dalam bekerja. Selain itu mereka pun akan lebih mudah untuk menilai prestasi kerja mereka. Hal itu dapat mendorong meningkatkan kinerja sistem informasi. Hasil penelitian ini juga didukung hasil penelitian yang dilakukan oleh Rosyid (1983), yang menyatakan bahwa ketidakpastian tugas dalam pengembangan sistem informasi berpengaruh positif pada kinerja sistem informasi.

Hasil pengujian menunjukkan bahwa H3 konsisten dengan penelitian sebelumnya. Dengan demikian ukuran organisasi memoderasi pengaruh partisipasi pemakai pada kinerja sistem 
informasi secara signifikan. Oleh karena itu dapat disimpulkan bahwa terdapat perbedaan pengaruh partisipasi pemakai sistem informasi pada kinerja sistem informasi di universitas dan non universitas. Dengan demikian kompleksitas pekerjaan di perguruan tinggi dapat menjelaskan perbedaan prediksi partisipasi pada kinerja.

Sedangkan pangujian pada hipotesis 4 konsisten dengan penelitian-penelitian sebelumnya. Hasil menunjukkan bahwa ukuran organisasi tidak memoderasi pengaruh ketidakpastian tugas pada kinerja sistem informasi. Hal ini menunjukkan tidak ada perbedaan antara universitas dan non-universitas berkaitan dengan pengaruh ketidakpastian tugas pada kinerja sistem informasi.

\section{Simpulan}

Penelitian ini bertujuan untuk memberi tambahan bukti empiris pengaruh partisipasi pemakai dan ketidakpastian tugas dalam pengembangan sistem informasi terhadap kinerja sistem informasi dengan memasukkan ukuran organisasi sebagai variabel moderasi. Simpulan hasil penelitian sebagai berikut:

1. Secara umum partisipasi pemakai dan ketidakpastian tugas berpengaruh pada kinerja sistem informasi, meskipun secara parsial partisipasi tidak berpengaruh pada kinerja sistem informasi. Variabel partisipasi pemakai dan ketidakpastian tugas mampu menjelasakan variasi kinerja sistem informasi sebesar $17,9 \%$, sedang sisanya dijelaskan variabel lain di luar model penelitian.

2. Ukuran organisasi memoderasi pengaruh partisipasi pemakai pada kinerja sistem informasi. Berarti dalam penelitian ini terdapat perbedaan prediksi tingkat partisipasi pemakai pada kinerja sistem informasi antara Universitas dan non Universitas di Daerah Istimewa Yogyakarta (DIY).

3. Namun ukuran organisasi tidak memoderasi pengaruh ketidakpastian tugas pada kinerja sistem informasi. Berarti dalam penelitian ini tidak terdapat perbedaan prediksi ketidakpastian tugas pada kinerja sistem informasi antara Universitas dan non universitas di Daerah Istimewa Yogyakarta.

\section{Keterbatasan dan Saran}

1. Proksi ukuran organisasi dengan mengelompokkan menjadi universitas dan nonuniversitas sesungguhnya kurang akurat mencerminkan ukuran kompleksitas pekerjaan dalam organisasi tersebut. Penelitian ke depan perlu mempertimbangkan secara lebih baik proksi yang akan digunakan.

2. Pengelola ataupun staf sistem informasi pada berbagai perguruan tinggi mempunyai karakteristik unik. Beberapa perguruan tinggi besar pengelola sistem informasi menggunakana tenaga karyawan dengan latar belakang pendidikan dan keterampilan sistem informasi. Namun banyak pula yang dirangkap oleh dosen dan bahkan ada yang dikelola oleh karyawan dengan level pendidikan yang kurang memadai.

3. Level analisis dalam penelitian ini adalah organisasi perguruan tinggi. Namun tidak semua objek adalah perguruan tinggi karena kesulitan akses, sebagai contoh ada objek perguruan tinggi berbentuk universitas, namun responden yang digunakan hanya berasal dari satu fakultas dalam universitasi tersebut. 
4. Setiap perguruan tinggi hanya direpresentasikan oleh tiga orang staf sistem informasi sehingga pemilihan ketiga staf seharusnya lebih hati-hati dengan mempertimbangkan jenis pekerjaan mereka stratejik atau administratif.

5. Variasi Variabel pada model memberikan kontribusi yang relatif kecil. Identifikasi kombinasi variabel baru atau pengembangan variabel mediasi dan moderasi penting dipertimbangkan sehingga model akan lebih komprehensif.

6. Keterbatasan instrumen-instrumen pengukuran muncul dalam penelitian ini. Beberapa instrumen variabel partisipasi, ketidakpastian tugas, dan kinerja sistem tidak mampu mengukur variabelnya dengan baik.

\section{Daftar Referensi}

Astuti, S. 2003. Pengaruh Diversitas Kemanfaatan dan Lingkup Pengembangan Kemanfaatan Teknologi Informasi terhadap Kepuasan Pemakai. Kompak. Jan - April: 94 -117.

Barki, H. dan Hartwick. 1994. Measuring User Participation, User Involvement and User Attitude. Management Information Sistem Quartely: 59 - 82.

Galbraith, J.R. 1997. Designing Complex Organization. Reading, MA, Addison Wesley.

Ghozali, I. 2001. Aplikasi Analisis Multivariate dengan Program SPSS. Andi Offset: Yogyakarta.

Irawati, A. dan Wijayanti, L.E. 1997. Pengaruh Partisipasi dan Kepuasan Pemakai terhadap Kinerja Sistem. JMK. 3 (1, Maret 2005).

Indarti dan Kentris. 2001. Faktor - faktor yang Mempengaruhi Intensitas Penggunaan Sistem Informasi Akuntansi. Jurnal Akuntansi dan Manajemen. Desember: 83 - 93.

Irawati, A. 2004. Pengaruh Partisipasi dan Ketidakpastian Tugas terhadap Kinerja Sistem Informasi. Jurnal Riset Akuntansi Indonesia. Desember: 22 - 30.

Jen, T.F. 2002. Faktor-faktor yang Mempengaruhi Kinerja Sistem Informasi Akuntansi. Jurnal Bisnis dan Akuntansi. IV (2).

Jogiyanto, H.M. 1995. Analisis dan Desain Informasi Pendekatan Terstruktur: Teori dan Praktek Aplikasi Bisnis. Andi Offset: Yogyakarta.

Koentjoro. 2000. Pengaruh Pembubaran Departemen Sosial terhadap Kepercayaan Diri dan Motif berprestasi Pegawai Departemen Sosial yang Mengikuti program Pendidikan Psikologi Panti. Laporan Penelitian (tidak diterbitkan). Organisasi Penelitian UGM. Yogyakarta.

Laudon D.S. 1996. Management Information System. 3 $3^{\text {rd }}$ Edition. South Western Publishing Company: New York.

Larry D.S. 1993. Performance Measurenment Guide. John Willey and Sons Inc..

Lau dan Elfreda A. 2004. Pengaruh Partisipasi Pemakai dan Kepuasan Pemakai dalam Pengembangan Sistem Informasi dengan Kinerja Sistem Informasi dengan Lima Variabel Moderasi. Jurnal Riset Akuntansi Indonesia. Jan: 23 - 43.

McKeen, D., J., et al. 1994. The Relationship User Participation and User Satifaction: An Investigation of Four Contingency Factors. Manajement Information System Quarterly. December: 97-117.

McLeod, R.J. 1998. Mangement Information System. $7^{\text {th }}$ Edition. MacMillan Publishing Company: New York.

Nizarul. 1998. Pengaruh Partisipasi Pemakai dalam Pengembangan Sistem Informasi dalam Hidayat. 2002, Pengaruh Partisipasi Pemakai Terhadap Kinerja Sistem Informasi: Ukuran Organisasi sebagai Variabel Antara, Tesis S-2, UGM.

Restuningdiah, N dan Indriantoro, N. 1999. Pengaruh Partisipasi terhadap Kepuasan Pemakai dalam Pengmbangan Sistem Informasi dengan Kompleksitas Sistem dan Pengaruh 
Pemakai sebagai Moderating Variabel. Jurnal Riset Akuntansi Indonesia. 3(2, Juli 2000).

Rockart, J.F and Flanery, L.S. 1983. The Manajement of End User Computing Construct in a University Setting. Decision Science. 24(6): 1187-1202.

Reksohadiprojo, S dan Handoko, T.H. 2001. Organisasi Perusahaan: Teori Struktur dan Perilaku. Edisi kedua. BPFE UGM: Yogyakarta.

Rosyid, H.F. 1983. Pengaruh Partisipasi terhadap Penyesuaian Tugas Teknologi Informasi. Skripsi (tidak diterbitkan). Fakultas Psikologi UGM: Yogyakarta.

Sardana, C. dan Hartati, S. 2005. Hubungan Antara Partisipasi Karyawan dalam Pengembangan Teknologi Informasi. Ringkasan Skripsi. Organisasi Penelitian UGM.

Sasmita, I.G. 2003. Faktor-faktor yang Mempengaruhi Kinerja Sistem Informasi Akuntansi pada Bank-bank Umum di Wilayah Surabaya. Skripsi Sarjana tak diterbitkan. STIE Perbanas Surabaya.

Sekaran, U. 2000. Research Methods For Business. $3^{\text {rd }}$ Edition. John Wiley \& Sons Inc.

Syam. 2000. Pengaruh Partisipasi dalam Pengembangan Sistem Informasi: Ketidakpastian Tugas sebagai Variabel Antara

Soegiharto. 2001. Influence Factor Affecting The Performance of Accounting Information System. Gajah Mada International Journal Of Business. 3 (2): 177 - 197.

Trito PB. 2005. Riset Statistik Parametrik. Andi Offset: Yogyakarta.

Whittaker, J.B. 1993. Measuring Performance dalam Lawrence, M., dan Low G., 1993, Exploring Individual User Satisfaction Within-Led Development, Management Information Systems Quarterly, Juny, hal. 195 - 208.

Wijayanti, L.E. dan Solichin, M. 2002. Pengaruh Partisipasi dalam Pengembangan Sistem Informasi: Ketidakpastian Tugas sebagai Variabel Moderasi. KOMPAK. 13(Januari April 2005): 69-88.

Wikanto, F.R. 2003. Hubungan Antara Kesesuaian Tugas Teknologi dan Pemanfaatan Sistem Informasi Berbasis Komputer dengan Kinerja Karyawan. Tesis (tidak diterbitkan). Fakultas Psikologi UGM: Yogyakarta.

\footnotetext{
* Heru Kurnianto Tjahjono, adalah staff pengajar dan peneliti di Fakultas Ekonomi, Universitas Muhammadiyah, Yogyakarta. Penulis adalah kandidat doktor Fakultas Psikologi, Universitas Gadjah Mada. Bidang minat penulis adalah dalam bidang perilaku organisasi dan manajemen sumber daya manusia. Herland Alfa Stevany, adalah aisten peneliti di Universitas Muhammadiyah Yogyakarta. Saran, masukan serta kritik yang membangun bisa langsung menghubungi penulis melalui email: heruutilitas@yahoo.com.
} 